\title{
MENGEMBANGKAN PENDIDIKAN BERMAKNA DI INDONESIA DAN IMPLIKASI-IMPLIKASINYA
}

\author{
Wasitohadi \\ Program Studi S1 Pendidikan Guru Sekolah Dasar (PGSD) \\ FKIP - Universitas Kristen Satya Wacana
}

\begin{abstract}
ABSTRAK
Pendidikan bermakna sebagai sistem pendidikan memiliki tiga ciri, yaitu mensejahterakan, menghargai martabat manusia, dan berkeadilan. Implikasinya bagi pendidikan, bahwa (a) pendidikan harus berorientasi pada subyek didik, artinya anak didik diperlakukan sebagai subyek, pendidikan diselenggarakan sesuai dengan perkembangan dan kemampuan anak, dan pendidikan itu mengembangkan anak didik secara utuh, (b) pendidikan yang dikembangkan harus humanis religius, yaitu pendidikan yang menekankan aspek kemerdekaan individu diintegrasikan dengan pendidikan religius agar dapat membangun kehidupan individu (sosial) yang memiliki kemerdekaan dan kemandirian, tetapi dengan tidak meninggalkan nilainilai keagamaan yang diikuti masyarakatnya, atau menolak nilai ketuhanan (ateisme), dan (c) kebijakan pendidikan yang deliberatif, sehingga kebijakan pendidikan yang dibuat memiliki hasil optimal.
\end{abstract}

Kata kunci: pendidikan bermakna, pendidikan humanis religius, kebijakan delibiratif

\section{PENDAHULUAN}

Di tengah adanya perbedaan dua pandangan bahwa "school does not matters" dan "school matters", ada yang memunculkan gagasan mengenai perlunya mengembangkan pendidikan bermakna di Indonesia. Munculnya gagasan semacam itu, antara lain didorong oleh adanya keprihatinan terhadap sistem pendidikan yang berkembang di persekolahan kita, yang dipersepsi oleh sebagian pihak kurang memberikan makna untuk memajukan kehidupan, mensejahterakan dan menghormati martabat manusia. Pandangan "school does not matters" antara lain ditokohi oleh Coleman. Menurutnya, penentu keberhasilan prestasi belajar anak adalah bukan sekolah, tetapi lebih ditentukan oleh faktor keluarga, terutama latar belakang tingkat pendidikan orang tua dan kondisi sosiokulturalnya. Bila orang tua mendukung, di manapun anak sekolah, dan dalam kondisi yang bagaimanapun sekolah itu, anak akan berhasil. Dengan kata lain, yang paling menyumbang terhadap prestasi anak di sekolah adalah "apa yang dibawa anak dari rumah". Pandangan yang berbeda disampaikan oleh Peter Mortimore dan kawan-kawannya, dengan mengatakan "School matters". Jadi, menurutnya, sekolah berdampak atau berpengaruh terhadap prestasi belajar siswa. Berbeda dengan Coleman, Peter Mortimore menggunakan metodologi yang dapat mengungkapkan tentang dampak sekolah, karena mereka melakukan survey dan wawancara mengenai "apa yang sesungguhnya dilakukan oleh guru".

Thomas Armstrong (2006) dalam bukunya "The Best Schools", misalnya, menyatakan bahwa dalam upaya perbaikan sekolah, kebanyakan sekolah terlalu berorientasi dan didominasi oleh wacana pengembangan prestasi akademik, dan cenderung mengabaikan wacana pengembangan manusia secara utuh. Dengan orientasi demikian, menurutnya, tujuan utama pendidikan sekolah adalah sekedar untuk melatih siswa agar lulus tes dan memperoleh peringkat yang baik, bukan agar mereka menerima dan mengolah gagasan-gagasan yang diterimanya, sehingga bermakna untuk kehidupan.

Tak heran, apabila kemudian muncul berbagai persepsi negatif, misalnya penilaian bahwa proses pendidikan formal dipandang hanya menghasilkan generasi baru yang "besar kepalanya, kerdil hatinya, dan tertangkup tangan kepeduliannya" (Kartono, 2004: 194). Ada pula yang menyatakan bahwa mestinya pendidikan di sekolah harus terus-menerus ditinjau apakah mengabdi pada kepentingan manusia 
atau sebaliknya, manusia justru menjadi korban dari institusi pendidikan. Demikian pula, ada fakta yang menunjukkan adanya pengelolaan sekolah yang cenderung menjadi lahan bisnis, pada masa Orde Baru sekolah malah cenderung dijadikan semacam wahana untuk menanamkan dan mempertahankan ideologi dan kekuasaan. Pengelolaan pendidikan semacam itu, potensial akan mengorbankan anak didik menjadi sekedar konsumen produk jasa yang disebut pelajaran, atau menjadi alat untuk mempertahankan dan melanggengkan kekuasaan, atau bahkan menjadikan anak didik semacam "sapi perah" bagi kepentingan di luar kepentingan anak didik sendiri.

Lalu, kemana seharusnya orientasi pelayanan pendidikan di arahkan? Jawaban atas pertanyaan itu perlu diperjelas agar karya pendidikan menjadi pelayanan yang bernilai dan bermakna dan patut diperjuangankan di dalam kehidupan masyarakat yang beradab. Tujuan pendidikan bukan sekedar membuat anak menjadi pandai, menjadi serba tahu dan serba bisa. Tugas pendidikan kita juga bukan hanya membuat anak bermoral tinggi. Tugas pendidikan kita adalah membimbing anak menjadi manusia yang berwatak, berilmu dan trampil sekaligus, sehingga pendidikan benar-benar dapat mensejahterakan dan menghormati martabat manusia.

Tulisan ini akan membahas tentang pendidikan bermakna dan implikasi-implikasinya bagi pendidikan. Agar sistematis, uraian akan dimulai dengan pembahasan tentang pendidikan bermakna, baru dilanjutkan dengan membahas mengenai implikasi-implikasinya bagi pendidikan, termasuk dalam hal itu akan dilakukan refleksi untuk melihat apakah dunia pendidikan di Indonesia sudah menerapkan implikasi-implikasi tersebut untuk menghasilkan sebuah pendidikan yang bermakna.

\section{PENDIDIKAN BERMAKNA}

Ada banyak variasi pendapat ahli mengenai apa yang dimaksud pendidikan bermakna, tergantung dari sudut pandang yang dipakai. Ada yang membedakan pendidikan bermakna dengan sistem pendidikan tradisionil. Bila sistem pendidikan tradisionil mengutamakan pembentukan pengetahuan, maka sistem pendidikan bermakna menunjuk pada sistem pendidikan yang mengutamakan pembentukan watak dalam arti pembentukan sistem nilai dan aktualisasinya. Dengan demikian, dalam pendidikan bermakna menempatkan pendidikan nilai sebagai sesuatu yang sentral dalam proses pendidikan, dan itu berarti memberi apresiasi yang tinggi kepada pembentukan watak. Tujuan pendidikan bermakna menurutnya adalah membina kepribadian, sekaligus bersamaan dengan itu untuk mengembangkan pengetahuan.

Mochtar Buchori(2003: 64) mengartikan pendidikan bermakna sebagai medium untuk mengantarkan peserta didik berkembang menjadi manusia cerdas yang integral. Dia mengartikan pula bahwa pendidikan bermakna sebagai "pembentukan watak dan kepribadian, di mana penguasaan ilmu, pengetahuan dan ketrampilan menjadi bagian integral di dalamnya. Dalam kerangka pendidikan bermakna, manusia berwatak menurutnya adalah manusia yang, di samping menjunjung tinggi norma-norma kehidupan serta mengenal dirinya sendiri; juga selalu bersedia untuk belajar, menambah dan memperdalam ilmunya, serta memperkaya dan mempertajam ketrampilannya. Dalam pendidikan bermakna, tugas sekolah adalah memberikan kemampuan belajar, pengetahuan yang penuh arti, dan menumbuhkan inspirasi untuk mengembangkan diri lebih lanjut. Selain itu, pendidikan bermakna mengharapkan peserta didik dapat memiliki kearifan, dapat membedakan antara pengetahuan yang bermakna atau tidak bermakna. Pendidikan bermakna mau mengembangkan bagaimana proses belajar mengajar yang penuh makna.

Sementara itu, Thomas Amstrong (2006), lebih melihat pendidikan bermakna sebagai pendidikan yang memberi keseimbangan perhatian antara wacana pengembangan prestasi akademik dengan wacana pengembangan kemanusiaan secara utuh. Namun, baginya, wacana pengembangan kemanusiaan itulah yang justru menandai "The best schools", yang menyesuaikan kurikulumnya dengan kebutuhan, minat, 
dan kemampuan para siswanya.

Menurutnya, asumsi yang diyakini dalam wacana pengembangan prestasi akademik antara lain: (a) bahwa isi dan ketrampilan akademik merupakan hal paling penting untuk dipelajari, (b) pengukuran pencapaian melalui tes peringkat dan standardisasi,(c) wacana pencapaian akademik mendukung kurikulum yang tepat, seragam dan diperlukan untuk semua siswa, (d) sangat berorientasi masa depan, (e) dapat melihat perbedaan yang hakiki di antara siswa, sekolah, kabupaten, provinsi, bahkan negara, (f) mendasarkan pada claim validitas pada penelitian yang berbasis keilmuan, dan lain-lain. Menurutnya, wacana pengembangan prestasi akademik memiliki beberapa konsekuensi negatif, antara lain: mengajar lebih untuk menghadapi tes/ujian, perhatian yang kurang terhadap individu, budaya dan perbedaan etnik, cenderung mengabaikan aspek kurikulum seperti musik, olah raga, vokasional, mengabaikan berbagai pengajaran yang bersifat positif yang tidak dapat diuji oleh data penelitian berbasis keilmuan, mendorong siswa nyontek dan meniru, mendorong terjadinya manipulasi hasil tes oleh guru dan petugas administrasi, dan lain-lain.

Sementara itu, wacana pengembangan manusia mempunyai perspektif yang secara substansi lebih luas daripada wacana pengembangan prestasi akademik (Thomas Amstrong, 2006:36). Istilah "akademik" merepresentasikan sesuatu yang bukan hidup dan itu obyektif dan terbatas, sedangkan "human" mewakili sebuah entitas yang hidup, subyektif dan tak terbatas, menyangkut kebutuhan, kepentingan dan kemampuan para siswanya. Asumsi yang diyakini, antara lain: (a) menjadi manusia utuh adalah aspek belajar yang penting, (b) proses yang penuh makna, terus menerus dan bersifat kualitatif, (c) kurikulum yang luwes, (d) berorientasi individu, (e) memberi pilihan-pilihan yang bermakna pada siswa, (f) menghargai masa lalu, kini dan masa depan setiap siswa, dan (g) mendasarkan validitas pada kekayaan pengalaman manusia.

Berdasarkan konsep-konsep tersebut, wacana pengembangan prestasi akademik rupanya lebih memperoleh tempat di masyarakat kita daripada wacana pengembangan manusia secara utuh. Hal ini disebabkan, karena masyarakat dan sekolah lebih merespon atau dipengaruhi oleh selera sistem pendidikan dan tuntutan pasar tenaga kerja yang memang sangat memberi tekanan pada wacana pengembangan prestasi akademik. Apa yang terjadi di sekolah dan kelas, oleh guru, dan yang dilakukan masyarakat, orang tua, termasuk kursus-kursus bimbingan belajar, lebih merespon pada tuntutan pengembangan dan pencapaian prestasi akademik. Selain itu, disebabkan juga oleh fakta bahwa pengembangan prestasi akademik lebih mudah dilaksanakan, lebih mudah mengukur proses dan hasil serta dampaknya dalam jangka pendek. Namun, konsekuensi praktis dari fenomena tersebut adalah bahwa pembangunan pendidikan melalui sekolah hanya bersifat parsial, tidak holistik. Pembangunan manusia seutuhnya melalui pendidikan, dengan demikian, tidak bisa tercapai karena cenderung diabaikan. Pikirannya mengejar skor saja, bukan mengembangkan anak. Anak lalu merasa bahwa belajar itu sebagai beban dan tekanan, yang dihayati tidak bermakna untuk dirinya.

Berdasarkan hasil refleksi atas uraian di atas, menurut kami pendidikan bermakna itu paling tidak harus memenuhi karakteristik sebagai berikut:

1. Pendidikan yang mensejahterakan

Secara ideal, pendidikan diselenggarakan untuk mewujudkan kesejahteraan bersama, yaitu terpenuhinya kebutuhan manusia, baik kebutuhan dasar kesejahteraan, maupun berbagai peluang-peluang yang potensial bisa diraih melalui pendidikan, seperti peluang kerja, aktifdalam LSM, dan lain-lain. Pendidikan juga mempersiapkan orang untuk memasuki persaingan sehat. Dalam pendidikan yang mensejahterakan, menurut Frans Magnis Suseno (1988), anak tidak dikungkung oleh rasa takut, tidak mengalami penindasan, tidak merasa diperlakukan tidak adil oleh siapapun, dan merasa dapat hidup dan belajar sesuai dengan cita-cita dan nilai-nilai sendiri. Hal seperti itu menuntut pengembangan pendidikan yang 
bukan hanya menawarkan wacana pengembangan prestasi akademik, tapi juga pengembangan aspek kemanusiaan secara utuh.

2. Pendidikan yang menghargai martabat manusia

Pendidikan yang bermakna adalah pendidikan yang manusiawi, yaitu pendidikan yang mendasarkan diri pada penghormatan terhadap martabat manusia dan hak asasinya yang mengalir darinya. Manusia harus diperlakukan sebagai manusia yang bermartabat yang memiliki akal budi, kehendak, dan kebebasan. Karena itu, manusia tidak boleh diperalat sebagai obyek. Pendidikan bertujuan agar peserta didik dapat berkembang sebagai subyek dalam berbagai dimensi kemanusiaannya. Karena itu, pelaku utama pendidikan adalah manusia itu sendiri sebagai subyek. Hak asasi manusia bisa dipandang sebagai usaha untuk menjabarkan isi dari martabat manusia itu. Pendidikan sendiri merupakan hak asasi setiap orang karena melalui pendidikan ia dapat meningkatkan dan mewujudkan martabatnya sebagai manusia.

Menurut Suyanto (2007), memartabatkan pendidikan tidak berarti menempatkan nilai etis pendidikan di atas tata nilai lainnya di dalam pergaulan sosial, politik, ekonomi bahkan budaya. Memartabatkan pendidikan berarti memberikan nilai rasa estetis kolektif maupun individual pada sisi perilaku dan etika pergaulan yang lebih bermartabat. Ini berarti bahwa di dalam konteks mengembangkan hubungan-hubungan antar individu atau kolektif penting untuk menempatkan pendidikan yang mengandung nilai etis dan estetika secara benar dan berbudaya.

3. Pendidikan bagi keadilan

Pendidikan yang bermakna harus merupakan pendidikan bagi keadilan (education for justice) sekaligus menjadi perwujudan keadilan sosial. Oleh karena itu, keadilan sosial merupakan tuntutan permanen yang diperjuangkan manusia. Manusia hanya dapat hidup layak sebagai manusia jika hakhaknya yang fundamental terpenuhi atau keadilan sosial tercapai. Semakin pendidikan bersifat elitis, dalam arti hanya kelompok elite saja yang menikmati pendidikan, semakin pendidikan jauh dari keadilan sosial. Semakin pendidikan merata ke segenap lapisan masyarakat, semakin keadilan sosial terwujud dalam pendidikan. Pendidikan bagi keadilan mengimplikasikan bahwa dalam pendidikan ditanamkan rasa keadilan sosial. Dalam tahap-tahap perkembangan kesadaran moral, prinsip keadilan harus semakin menjadi pertimbangan atau motivasi dalam menentukan tindakan.

\section{BEBERAPA IMPLIKASINYA BAGI PENDIDIKAN}

\section{Pendidikan dan Perkembangan Anak}

Agar pendidikan itu bermakna, dalam arti mensejahterakan, menghormati martabat manusia dan adil, maka pertama-tama pendidikan itu hendaknya berorientasi dan demi pengembangan anak didik. Perkembangan potensi anak didik secara optimal merupakan sasaran utama pelayanan pendidikan. Optimal dalam hal ini, menurut H. Noeng Muhadjir (2003:34), menunjuk pada perkembangan yang disesuaikan dengan kemampuan subyek masing-masing, bukan penyesuaian dengan tujuan atau target yang hendak dicapai. Ini berbeda dengan pengembangan maksimal, yang berarti pengembangan sesuai dengan tujuan atau target yang hendak dicapai. Pendidikan yang berorientasi pada anak didik mempunyai tiga pengertian, yaitu (a) anak didik diperlakukan sebagai subyek, (b) pendidikan diselenggarakan sesuai dengan perkembangan dan kemampuan anak, dan (c) pendidikan itu mengembangkan anak didik secara utuh.

Pertama, dalam pendidikan anak didik adalah subyek yang bersifat unik yang mencapai tujuan pendidikan secara bertahap. Masing-masing anak memiliki kekhususan sendiri, memiliki kemampuan yang tidak sama, berbeda satu dengan yang lain. Sebagai subyek, ia melewati proses perkembangan yang panjang, masing-masing menurut usianya dengan alam pikirannya sendiri-sendiri, masing-masing mampu 
mengambil sikap tertentu secara pribadi, masing-masing memiliki kehendak yang berbeda, masing-masing mempunyai perasaan yang berlainan satu dengan yang lain, masing-masing memiliki hubungan yang khusus dengan Sang Penciptanya. Begitulah masing-masing anak didik mempribadi dan unik.

Oleh karena itu, memperlakukan anak didik sebagai obyek dan menggeneralisir mereka merupakan perlakuan yang tidak tepat. Pendidikan semacam itu "membonsai" harkat dan martabat anak didik sebagai manusia muda yang seharusnya memiliki kemampuan dan kebebasan berkembang sebagai panggilan hidup dari Penciptanya, menjadi manusia yang kerdil karena tidak berkembang secara optimal sesuai dengan fitrahnya. Akibatnya, bukan saja dapat membuat anak kehilangan sikap kritis mereka, tapi juga dapat menghambat perkembangan kemandirian anak dalam belajar.

Anak didik sebagai subyek sebaiknya dibimbing dan didampingi agar dapat berkembang dan mengembangkan diri sendiri. Pendampingan bersifat dialogis, bukan indoktrinatif. Pendidik sebagai pendamping dan anak didik sebagai yang didampingi saling menghormati, saling terbuka, dan saling percaya. Pendidik dan anak didik keduanya sama-sama sebagai subyek, perbedaannya adalah yang satu lebih dulu lahir dan atau lebih banyak belajar, sedangkan yang lain lahir kemudian dan atau lebih sedikit belajar. Pendampingan yang bersifat pribadi, cura personalis, lebih tepat dari pada pendampingan klasikal. Pendidik hendaknya mengenal anak didiknya satu persatu.

Kedua, pendidikan harus dilaksanakan sesuai dengan perkembangan dan kemampuan anak. Anak didik berkembang secara bertahap, mereka bukanlah produk instan. Anak didik mengalami perkembangan dari waktu ke waktu, baik segi fisik, psikis, sosial maupun spiritual, dengan kecepatan perkembangan yang tidak selalu sama. Demikian pula, dari segi kemampuan, mereka juga berbeda satu sama lain. Talenta mereka berbeda-beda. Ada yang lebih mampu mempelajari eksakta, tetapi ada pula yang lebih cepat mempelajari bahasa. Ada yang lebih berminat dan cakap pada ketrampilan fisik, tetapi ada pula yang lebih memiliki kecerdasan otak. Dalam kondisi seperti itu, pendidikan perlu memberi perhatian kepada perkembangan dan kemampuan masing-masing anak didik.

Ketiga, pengembangan anak didik perlu dilakukan secara utuh. Pendidikan haruslah memperhatikan kedua dimensi hakiki manusia, individualitas dan sosialitas. Masing-masing individu dengan keunikan, bakat, dan karakternya masing-masing harus mendapat perhatian. Tetapi pendidikan juga berfungsi untuk membangun sosialitas manusia sejak dini. Pendidikan harus memupuk "modal sosial", yaitu serangkaian nilai dan norma sosial yang harus dihayati oleh setiap anggota kelompok, seperti keadilan sosial, tenggang rasa, dan saling percaya. (M. Sastrapratedja, 2004:16). Bandingkan dengan pendapat Zamroni (2007:114), yang menyatakan bahwa modal sosial merupakan suatu jalinan kerjasama di antara warga yang saling menguntungkan dan didasarkan pada trust. Dengan modal sosial ini muncul berbagai asosiasi di masyarakat yang kuat, yang menjadi simbol-simbol kebebasan, dan sekaligus menjadi perisai yang dapat menjamin kelangsungan kebebasan dan melawan ancaman atas kebebasan baik yang datang dari negara maupun dari “pasar". Sementara itu, menurut Ridell (1997), ada tiga parameter modal sosial, yaitu kepercayaan (trust), norma-norma (norms) dan jaringan-jaringan (networks).

Selain itu, pendidikan juga perlu mengembangkan bukan hanya kecerdasan intelektual saja, tetapi juga kecerdasan emosional dan kecerdasan spiritual. Kecerdasan intelektual lebih terarah pada obyekobyek di luar diri manusia (outward looking), sedangkan kecerdasan emosional lebih terarah pada obyekobyek di dalam diri manusia (inward looking). Selain itu, kecerdasan intelektual lebih diunggulkan dalam dunia akademis, engineering dan teknologi. Sedangkan kecerdasan emosional lebih diunggulkan untuk mengenal dan memahami diri sendiri serta sesama. Menurut Daniel Goleman, kecerdasan emosional lebih unggul daripada kecerdasan intelektual jika dasar penentunya adalah keberhasilan hidup di tengah masyarakat. Sementara itu, kecerdasan spiritual merupakan kecerdasan yang dianggap lebih mendalam. 
Kecerdasan ini melekat dan bersumber kepada kodrat manusia itu sendiri sebagai ciptaan Sang Pencipta. Kecerdasan ini dipandang menjadi dasar, acuan atau kerangka dalam penciptaan dan pemahaman atas lahirnya karya-karya cemerlang dan agung, yang menjadi tonggak perkembangan peradaban umat manusia.

Bila kita melakukan refleksi terhadap kondisi dunia pendidikan di Indonesia, tampak bahwa meskipun disadari pentingnya prinsip child oriented, tapi yang terjadi dalam praktik prinsip tersebut belum dilaksanakan secara optimal. H.A.R Tilaar (2006:19) menyatakan bahwa di Indonesia telah terjadi obyektifikasi anak. Katanya, "obyektifikasi anak Indonesia telah membawa proses pendidikan kepada proses reifikasi. Proses reifikasi pendidikan berarti membendakan segala sesuatu yang dijadikan sebagai obyek. Anak Indonesia sebagai obyek adalah sesuatu yang dapat diukur, yang dapat memenuhi tuntutantuntutan tertentu, yaitu kompetensi-kompetensi yang dapat diukur."

Menurut penulis, di Indonesia umumnya masih lebih menerapkan teacher centre strategies dan material centre strategies katimbang student centre strategies. Teacher centre strategies adalah strategi belajar mengajar yang berpusat pada guru. Dalam hal ini, mengajar adalah penyampaian informasi kepada peserta didik. Dalam pengertian yang demikian, maka tekanan pada strategi belajar mengajar terletak pada guru itu sendiri, di mana guru sebagai sumber informasi mempunyai posisi yang sangat dominan. Belajar dalam pendekatan ini adalah menerima informasi dari guru.

Sedangkan dalam material centre strategies, strategi belajar mengajar lebih berpusat pada materi. Belajar dengan demikian adalah usaha untuk menguasai informasi. Dalam strategi belajar mengajar yang demikian, menyebabkan (1) kecenderungan pada dominasi kognitif di mana pendidikan afektif dan ketrampilan kurang mendapatkan tempat yang seimbang dalam rangka peningkatan kualitas manusia Indonesia seutuhnya. Selain itu, materi pelajaran yang disampaikan di dalam kelas, dan yang di muat dalam buku teks, akan makin usang dengan pesatnya perkembangan ilmu pengetahuan dan teknologi. Materi pelajaran itu lebih berfungsi sebagai masukan (input) yang akan luluh dalam proses belajar mengajar. Sekolah diciptakan untuk tempat para siswa belajar. Dengan pengertian ini, mestinya guru dan berbagai fasilitas pembelajaran yang lain disediakan untuk membantu siswa melaksanakan kegiatan belajarnya. Siswa menjadi pusat seluruh kegiatan belajar mengajar di sekolah (student centered). Peran guru di depan kelas cenderung diposisikan sebagai motivator, mediator, fasilitator dan evaluator. Bila ada guru yang jauh lebih aktifmengajar dibandingkan siswanya di sekolah, perilaku tersebut jelas menyalahi dasardasar pembelajaran. Jadi, dalam hal ini guru memang diharapkan menjadi ujung tombak bagaimana prinsip student centered itu bisa diterapkan secara optimal, yang didukung oleh segenap komponen sistem pendidikan lainnya.

Pendidikan di Indonesia, juga belum memperhatikan secara optimal baik kondisi subyektif/internal peserta didik maupun kondisi objektif dunia dan masyarakat kita. Pembelajaran mestinya adaptif, dalam arti memperhatikan latarbelakang, kecerdasan, gaya belajar peserta didik, serta memperhatikan segala hal yang terjadi di dunia dan masyarakat yang berpengaruh terhadap pendidikan. Namun yang terjadi dalam pendidikan kita, pendidikan masih relatif sangat tradisionil, sangat klasikal, dan tidak dimulai dengan mengidentifikasi kondisi dan karakteristik peserta didik.

\section{Pendidikan yang humanis religius}

Agar pendidikan bermakna, pendidikan yang dikembangkan adalah pendidikan yang manusiawi. Pendidikan bertujuan untuk membantu manusia menjadi semakin manusiawi. Tujuan manusiawi itu hanya dapat dicapai melalui jalan yang manusiawi pula. Karena itu, pendidikan harus humanis religius. Istilah pendidikan humanis-religius mengandung dua konsep pendidikan yang ingin diintegrasikan, yaitu pendidikan humanis dan pendidikan religius. Pengintegrasikan dua konsep pendidikan ini dengan tujuan untuk dapat 
membangun sistem pendidikan yang dapat mengintegrasikan dari keduanya atau mengurangi kelemahannya (Sodiq A. Kuntoro, 2008). Pendidikan humanis yang menekankan aspek kemerdekaan individu diintegrasikan dengan pendidikan religius agar dapat membangun kehidupan individu (sosial) yang memiliki kemerdekaan, tetapi dengan tidak meninggalkan nilai-nilai keagamaan yang diikuti masyarakatnya, atau menolak nilai ke-Tuhanan (ateisme).

Suyata (2008) mengartikan pendidikan humanis religius sebagai pendidikan yang menempatkan manusia sebagai sentral, namun dikendalikan oleh nilai-nilai agama. Dalam istilah Paul Suparno (2002: 25), pendidikan yang diselenggarakan itu didasari dan diarahkan ke tujuan akhir, yaitu memuliakan Tuhan. Dalam kerangka inilah karya pendidikan akan memiliki fondasi dan arah yang mendasar. Dalam hal itu, M. Sastrapratedja (2004:21) menyatakan bahwa nilai-nilai kemanusiaan harus menjadi dasar pendidikan. Nilai-nilai kemanusian yang telah disepakati bangsa Indonesia adalah nilai-nilai dasar yang dirumuskan dalam Pancasila. Karena itu, sering dikatakan, Pancasila itu humanistik dan universalistik. Dikatakan humanistik karena memuat nilai-nilai kemanusiaan, dan universalistik karena nilai-nilai itu bersifat mendasar, sehingga berlaku bagi setiap orang. Karena itu pula pendidikan nasional harus bertumpu pada nilai-nilai Pancasila. Maka pendidikan yang berdasarkan nilai-nilai kemanusiaan Pancasila akan memiliki lima ciri, yaitu hormat terhadap keyakinan religius setiap orang, hormat terhadap martabat manusia dan hak-hak asasi, berwawasan kebangsaan, demokratis, serta menjunjung dan menegakkan keadilan sosial bagi seluruh rakyat Indonesia.

Pendidikan humanis sebagai pemikiran pendidikan telah berkembang dengan mengadopsi prinsipprinsip pendidikan dari dua aliran, yaitu progressivisme dan eksistensialisme. Tetapi pendidikan humanis juga memperoleh dukungan dari para ahli psikologi humanistik, dan ahli pendidikan kritis romantis (Knight, George R., 1982). Prinsip-prinsip pendidikan humanis yang diambil dari prinsip progressivisme adalah prinsip pendidikan yang berpusat pada anak (child centered), peran guru yang tidak otoriter, fokus pada keterlibatan dan aktivitas siswa, dan aspek pendidikan yang demokratis dan kooperatif.

Prinsip-prinsip pendidikan ini adalah sebagai reaksi terhadap pendidikan tradisionil yang menekankan pada metode pengajaran formal yang kurang memberi kebebasan kepada siswa, sehingga siswa menjadi tidak kreatif yang sekedar mengikuti program pendidikan yang ditetapkan oleh orang dewasa. Prinsipprinsip pendidikan tradisionil yang ditolak humanis adalah (1) guru yang otoriter, (2) metode pengajaran yang menekankan pada buku teks semata, (3) belajar pasif yang menekankan mengingat data atau informasi yang diberikan guru, (4) pendidikan yang membatasi pada ruang kelas sehingga terasing dari realitas kehidupan sosial, (5) penggunaan hukuman fisik atau rasa takut sebagai bentuk untuk membangun disiplin.

Sejalan dengan prinsip-prinsip pendidikan yang telah disebutkan di atas, maka para pendidik humanis memiliki pandangan tentang pendidikan sebagai berikut.

a. Tujuan pendidikan dan proses pendidikan berasal dari anak (siswa). Oleh karenanya kurikulum dan tujuan pendidikan menyesuaikan dengan kebutuhan, minat dan prakarsa anak.

b. Siswa adalah aktif, bukan pasif. Anak yang memiliki keinginan belajar dan akan melakukan aktivitas belajar apabila mereka tidak difrustrasikan belajarnya oleh orang dewasa atau penguasa yang memaksakan keinginannya.

c. Peran guru adalah sebagai penasehat, pembimbing, teman belajar, bukan penguasa kelas. Tugas guru membantu siswa belajar, sehingga siswa memiliki kemandirian dalam belajar. Guru berperan sebagai pembimbing dan yang melakukan kegiatan mencari dan menemukan pengetahuan bersama siswa. Tidak boleh ada pengajaran yang bersifat otoriter, di mana guru sebagai penguasa dan murid menyesuaikan. 
d. Sekolah sebagai bentuk kecil dari masyarakat luas. Pendidikan seharusnya tidak sekedar dibatasi sebagai kegiatan di dalam kelas dengan dibatasi empat dinding sehingga terpisah dari masyarakat luas. Karena pendidikan yang bermakna adalah apabila pendidikan itu dapat dimanfaatkan dalam kehidupan masyarakat;

e. Aktivitas belajar harus terfokus pada pemecahan masalah, bukan sekedar mengajarkan mata pelajaran. Pemecahan masalah adalah bagian dari kegiatan kehidupan oleh karenanya pendidikan harus membangun kemajuan siswa untuk memecahkan masalah. Kegiatan pendidikan bukan sebagai pemberian informasi atau data dari guru pada siswa yang terbatas sebagai aktivitas mengumpulkan dan mengingat kembali pengetahuan statis;

f. Iklim sekolah harus demokratis dan kooperatif. Karena kehidupan di masyarakat selalu hidup bersama dengan orang lain, maka setiap orang harus mampu membangun kooperasi dengan orang lain. Namun dalam sistem pendidikan tradisionil, siswa sering dilarang untuk berbicara, berpindah tempat, atau bekerjasama dengan siswa lain. Iklim demokratis dalam kelas adalah dibutuhkan agar siswa dapat hidup secara demokratis di masyarakat.

Atas dasar konsep seperti itu, pendidikan yang diwarnai kekerasan, yang mereduksi peserta didik menjadi obyek, bertentangan dengan tujuan pendidikan humanis religius. Demikian pula, pendidikan yang opresif, yang tidak memungkinkan pengembangan kreativitas dan kemandirian subyek didik, tidak akan mencapai tujuan-tujuan pendidikan, yaitu memekarkan potensi, menguasai ilmu dan teknologi, memupuk kerja sama, menciptakan sikap saling menghormati, menumbuhkan sikap apresiatif terhadap perbedaan agama dan budaya, membangun komitmen untuk mengabdikan ilmu dan teknologi bagi kemanusiaan.

Demikian pula, struktur dan institusi sosial, politik dan pendidikan yang diciptakan manusia dapat menciptakan kondisi yang kurang manusiawi dan menekan manusia serta tidak melayani kebebasan dan pengembangan diri manusia. Karena itu, harus terus menerus diadakan reformasi terhadap struktur dan institusi sosial manusia, supaya melayani dan tidak memperbudak manusia (M. Sastrapratedja, 2004:15).

\section{Kebijakan pendidikan yang deliberalif}

Kata "deliberasi" berasal dari kata latin deliberatio yang artinya "konsultasi", "menimbang-nimbang" atau "musyawarah". Kebijakan pendidikan bersifat deliberatif, jika proses pemberian alasan atas suatu penetapan kebijakan pendidikan diuji lebih dahulu lewat konsultasi publik atau lewat diskursus publik. Kebijakan pendidikan yang deliberatif ingin meningkatkan intensitas partisipasi warga negara dalam proses pembentukan aspirasi dan opini agar kebijakan-kebijakan yang dihasilkan semakin mendekati harapan pihak yang diperintah. Intensifikasi proses deliberasi lewat diskursus publik itu merupakan jalan agar dampak kebijakan yang dibuat memiliki hasil optimal, yaitu berguna untuk meningkatkan kesejahteraan bersama, menghormati martabat manusia dan semakin adil.

\section{PENUTUP}

Dari pembahasan di atas dapat disimpulkan/dirangkumkan hal-hal sebagai berikut:

1. Ada variasi pendapat ahli mengenai apa arti pendidikan bermakna, tergantung dari sudut pandang yang dipakai. Ada yang mengartikan pendidikan bermakna sebagai sistem pendidikan yang mengutamakan pembentukan watak dalam arti pembentukan sistem nilai dan aktualisasinya. Tujuan pendidikan bermakna adalah membina kepribadian sekaligus mengembangkan pengetahuan.

2. Mochtar Buchori mengartikan pendidikan bermakna sebagai medium untuk mengantarkan peserta didik berkembang menjadi manusia cerdas yang integral. Pendidikan bermakna sebagai "pembentukan watak dan kepribadian, di mana penguasaan ilmu, pengetahuan dan ketrampilan menjadi bagian integral di dalamnya. 
3. Thomas Amstrong memahami pendidikan bermakna sebagai pendidikan yang memberi keseimbangan perhatian antara wacana pengembangan prestasi akademik dengan wacana pengembangan kemanusiaan secara utuh.

4. Dalam pendidikan bermakna: (a) pendidikan itu mensejahterakan subyek didik, dalam arti anak tidak dikungkung oleh rasa takut, tidak mengalami penindasan, tidak merasa diperlakukan tidak adil oleh siapapun, merasa dapat hidup dan belajar sesuai dengan cita-cita dan nilai-nilai sendiri; (b) pendidikan itu menghargai martabat manusia dan hak asasinya yang mengalir darinya. Manusia diperlakukan sebagai manusia yang bermartabat yang memiliki akal budi, kehendak, dan kebebasan; (c) pendidikan bagi keadilan sekaligus menjadi perwujudan keadilan sosial. Pendidikan bagi keadilan mengimplikasikan bahwa dalam pendidikan ditanamkan rasa keadilan sosial.

5. Implikasinya bagi pendidikan, antara lain bahwa (a) pendidikan harus berorientasi pada subyek didik, artinya anak didik diperlakukan sebagai subyek, pendidikan diselenggarakan sesuai dengan perkembangan dan kemampuan anak, dan pendidikan itu mengembangkan anak didik secara utuh; (b). pendidikan yang dikembangkan harus humanis religius. Pendidikan humanis yang menekankan aspek kemerdekaan individu diintegrasikan dengan pendidikan religius agar dapat membangun kehidupan individu (sosial) yang memiliki kemerdekaan dan kemandirian, tetapi dengan tidak meninggalkan nilainilai keagamaan yang diikuti masyarakatnya, atau menolak nilai ke-Tuhanan (ateisme). Atau, pendidikan humanis religius adalah pendidikan yang menempatkan manusia sebagai sentral, namun dikendalikan oleh nilai-nilai agama dalam semangat menegakkan Pancasila; dan (c) kebijakan pendidikan yang deliberatif.

\section{DAFTAR PUSTAKA}

BASIS No. 07-08, Juli-Agustus 2000, "Pendidikan Hanya Menghasilkan Air Mata".

Bernadib, Imam. 1994. Hand Out Filsafat Pendidikan. Yogyakarta: Progdi Ilmu Filsafat PPS UGM.

Buchori, Mochtar. 1994. Ilmu Pendidikan dan Praktek Pendidikan Dalam Renungan, Kerjasama PT. Tiara Wacana, Yogyakarta dengan IKIP Muhammadiyah Jakarta Press.

Buchori, Mochtar. 1994. Spektrum Problematika Pendidikan di Indonesia. Yogyakarta: PT. Tiara Wacana.

Buchori, Mochtar. 2001. Pendidikan Antisipatoris.Yogyakarta: Penerbit Kanisius.

Darmaningtyas. 1999. Pendidikan Pada dan Setelah Krisis. Yogyakarta: Pustaka Pelajar.

Dimyati, Muhammad. 1998. Landasan Kependidikan. Jakarta: Depdikbud.

Dodi Nandika. 2007. Pendidikan di Tengah Gelombang Perubahan. Jakarta: LP3ES.

Doni Koesoema. 2007. Pendidikan Karakter. Strategi Mendidik Anak di Zaman Global. Jakarta: Grasindo.

Driyarkara. 2007. Karya Lengkap Driyarkara. Jakarta: PT. Gramedia.

Dwi Siswoyo. 2007. Ilmu Pendidikan. UNY Press: Yogyakarta.

George R. Knight. 1982. Issues and Alternatives in educational Philosophy. Michigan: Andrews University Press. 
Satya Widya Vol.28, No.1, Juni 2012: 83-92

H. Noeng Muhadjir. 2003. Ilmu Pendidikan dan Perubahan Sosial. Yogyakarta: Penerbit Rake Sarasin. Paul Suparno. 2002. Reformasi Pendidikan. Yogyakarta: Penerbit Kanisius.

Peter Mortimore. 1988. School Matters. England: Open Books Publishing Ltd.

Tilaar, HAR. 1999. Pendidikan, Kebudayaan, dan Masyarakat Madani Indonesia. Bandung: Penerbit PT. Remaja Rosdakarya.

Yayasan Bhumi Aksara. 2003. Refleksi Tentang Pendidikan Bermakna Menuju Indonesia Baru. Jakarta. 